高齢者の腸疾患

\title{
5. 高齢者の下部消化管出血の特徵と治
}

療

Lower gastrointestinal bleeding in elderly people

\begin{tabular}{|c|c|c|c|c|c|c|c|}
\hline 井上 & 内藤 & 裕二 & 冨田 & 侑里 & 橋本 & 光 & 杉野 \\
\hline 俊文 & 土肥 & 統 & 吉田 & 直久 & 鎌田 & 和浩 & 内山 \\
\hline 石川 & 高木 & 智久 & 小西 & 英幸 & 伊藤 & 義人 & \\
\hline
\end{tabular}

\section{要 約}

本邦では超高齢社会を迎え，下部消化管出血において高齢者が占める割合が増加している．高齢者の下部 消化管出血の原因疾患としては大腸息室出血が最多であり, 他に, 良性の直腸肛門病変, 大腸炎, 大腸悪性 疾患, 大腸内視鏡治療後出血, 大腸ポリープ, angiodysplasia などがあるが, 四分の一では原因が不明であ る. 超高齢社会においては下部消化管出血を認めた場合は上記疾患を鑑別する必要がある．また原因不明の 消化管出血には心・血管疾患に伴う消化管出血なども念頭に診療を行う必要がある.

Key words 高齢者, 下部消化管出血, 大腸媳室出血, 急性出血性直腸潰瘍,

後天性フォンウィルブランド症候群

（日老医誌 $2020 ； 57 ： 436-440$ )

下部消化管出血の原因疾患は年齢によ り変化する

下部消化管出血の原因疾患としては 60 歳未満では 頻度の順に，(1)良性の直腸肛門病変，(2)原因不明，(3) 大腸炎, (4)大腸憩室出血, 5)大腸悪性疾患, (6)大腸内 視鏡治療後出血, (7)大腸ポリープなどがある. 60 歳 以上では(1)大腸憩室出血, (2)原因不明, (3)良性の直腸 肛門病変，(4)大腸炎，5)大腸悪性疾患，66腸内視鏡 治療後出血, (7)大腸ポリープ, 8)angiodysplasiaなど がある（表 1） ${ }^{11}$ 。年齢によって原因疾患の頻度の傾
向が変化することを念頭に診療を行う必要がある。い ずれの年齢においても四分の一程度が原因不明である ことも問題と考えられる。本項では大腸憩室出血, 良 性の直腸肚門病変, angiodysplasia などに関する特徵 と治療について述べる.

\section{高齢者の大腸㮩室出血は増加している}

本邦からの報告では，下部消化管出血において 70 歳以上の高齢者が占める割合は，1995 年〜2006 年で は 23.7\%, 2007 年〜2013 年では 39.6\% と有意に増加

京都府立医科大学大学院医学研究科消化器内科学

連絡責任者: 井上 健 京都府立医科大学大学院医学研究科消化器内科学〔 $\bar{T} 602-8566$ 京都市上京区河原町通広小路上る梶井町 465]

doi: 10.3143 /geriatrics.57.436 
している ${ }^{2)}$ またた，下部消化管出血において大腸憩室 出血が占める割合は, 1995 年〜2006 年では 5.9\%, 2007 年〜2013 年では $23.0 \%$ と有意に増加し, 2007 年〜2013 年においては下部消化管出血の原因で最多となった (図 1） ${ }^{2)}$. 数十年前と比較して下部消化管出血の原因 は大きく変化したと考えられ，低用量アスピリンや非 ステロイド性抗炎症薬服用者の増加がその要因と推定 されている゙).

さらに, 大腸憩室出血は高齢者に多く, 本邦では男 性に多いとされている．大腸憩室出血の年齢に関して は, 60 歳以上が $80.6 \%$, 性別に関しては, 男性が $63.0 \%$ であった ${ }^{2}$. 本邦の大腸憩室出血の死亡率は $1 \%$ 程度 であった．高齢男性で死亡率が高くなるが，他の下部 消化管出血より死亡率が低いと報告されている ${ }^{4)}$.

急性下部消化管出血にて，大腸憩室出血を疑った場 合，初回診断法として大腸内視鏡検査が推奨される.

\begin{tabular}{l} 
表 160 歳以上の下 \\
部消化管出血の原因 \\
疾患 \\
\hline 60 歳以上 \\
(1)大腸憩室出血 \\
(2) 原因不明 \\
(3)良性の直腸肛門病変 \\
(4)大腸炎 \\
(5)大腸悪性疾患 \\
(6)大腸内視鏡治療後出血 \\
(7)大腸ポリープ \\
(8)大腸 angiodysplasia \\
\hline
\end{tabular}

また禁忌例を除き，傾向洗浄液を用いた前処置が推奨 される. また患者や施設の状況に応じて CTを行うこ とが提案される。

(1)活動性出血, (2)非出血性露出血管, (3)除去によっ て(1)または(2)を示す付着凝血塊は最近出血した徴候と 定義され，このような症例においては大腸憩室に内視 鏡的止血術を実施することを推奨する5). (1)(2)の内視 鏡所見を提示する（図 2)。大腸憩室出血に対する内 視鏡的止血術としては, クリップ止血法, 高張食塩水 エピネフリン局注法，結杽術などが用いられる。われ われの観察研究では, (1)(2)(3の内視鏡所見を呈し，内 視鏡的止血術を施行した症例における一力月以内の再

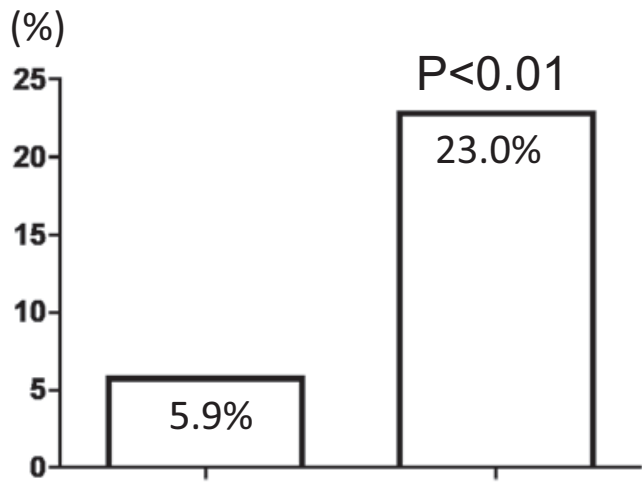

1995-2006

\section{7-2013}

図 1 下部消化管出血における大腸憩室出血が占める 割合の変化

1995 年〜 2006 年では $5.9 \%, 2007$ 年〜 2013 年では $23.0 \%$ と有意に増加している。

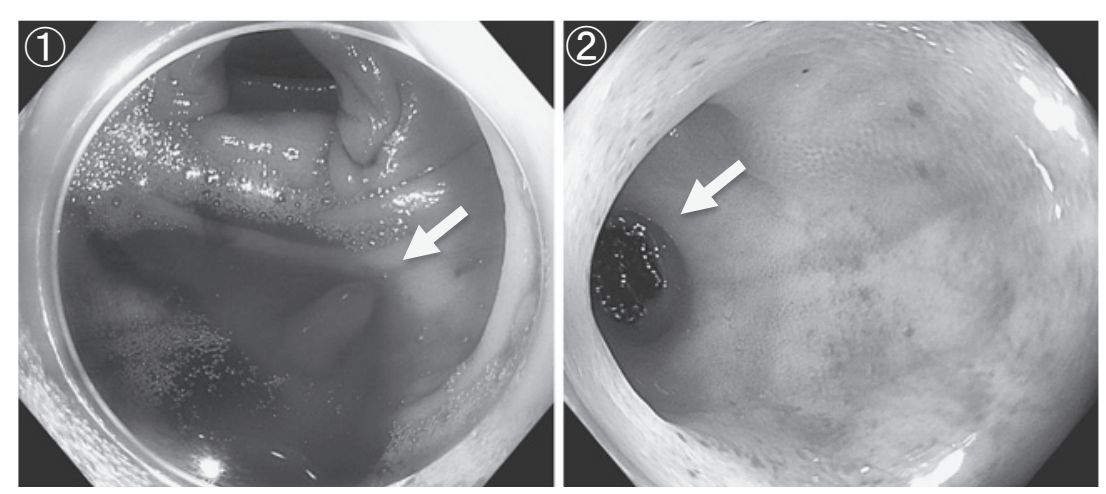

図 2 大腸䟤室出血における最近出血した徴候 (1)活動性出血, (2)非出血性露出血管 


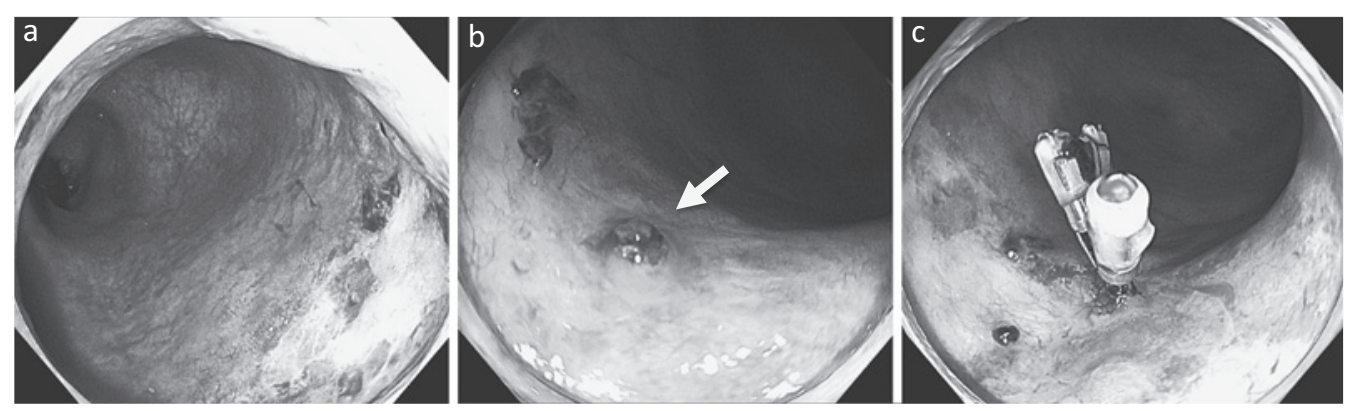

図 3 急性出血性直腸潰瘍に対する内視鏡的止血術

a：下部直腸に潰瘍を認める, b : 潰瘍底に露出血管を認める, c : クリップにて止血処置を行った.

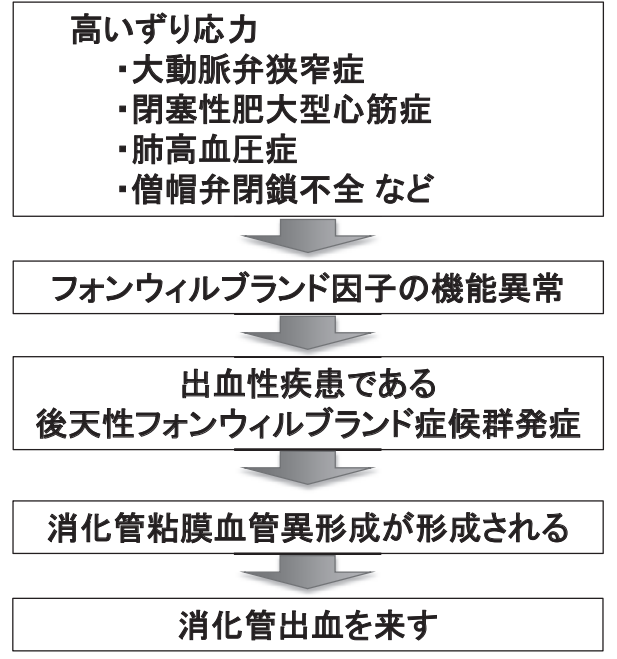

図 4 高ずり応力により引き起こされる後天性フォン ウイルブランド症候群

大動脈弁狭窄部などにおいて，止血因子であるフォ ンウィルブランド因子がずり応力依存的に特異的切 断酵素であるADAMTS13によって切断される. 高 ずり応力により分解が立進してフォンウィルブラン ド因子高分子多量体が欠損・減少する.

出血率は約 $25 \%$ であった. また, 本邦の大腸憩室出 血の長期の再出血率は， 1 年後で 20〜 35\%，2 年後で 33〜 42\% であると報告されている ${ }^{6}$. 大腸憩室出血に おいてはこのように再出血を比較的高率で認めること が課題と考えられる．大腸内視鏡で止血困難な，大量 で継続する出血や出血源が同定できないような持続 性・再発性の大腸㕰室出血に動脈塞栓術を実施するこ とが推奨されている.内視鏡治療や動脈塞栓術が不成 功であった重症例に対しては緊急大腸切除術が適応と
なる。

\section{高齢者の良性の直腸肛門病変は動脈硬 化性疾患が高率に合併する}

急性出血性直腸潰瘍について述べる。中村ら ${ }^{7}$ は, 急性出血性直腸潰瘍の疾患概念を “動脈硬化の要因を 背景に血流低下の準備状態にある高齢者が，何らかの 理由で寝たきり状態になり，下部直腸の粘膜血流低下 を来し惹起される虚血性粘膜障害である”と提唱した。 中村らの 85 例の検討 ${ }^{7)}$ では, 平均 $73.8 \pm 11.1$ 歳と, 大 半が 65 歳以上の高齢者で占められていた。これら 85 症例において，原疾患は脳血管障害 $(40.0 \%)$ だけで なく，肺炎 $(12.0 \%)$, 大腿骨頸部骨折 $(10.6 \%)$ など も認めた. 併存症としては患者の大半が高齢者である ため高血圧 $(51.8 \%)$ や糖尿病 $(20.0 \%)$ など, 動脈 硬化性疾患の高率な合併が認められた. 治療としては, 潰瘍底に露出血管を認める場合は, 止血鉗子による凝 固処置やクリップなどが用いられる。クリップを用い て止血を行った症例の内視鏡画像を提示する（図 3). 再出血を予防するために体位を適宜, 左右側臥位に変 換することが望ましいとされている.

大川ら に ${ }^{8)}$ にると，鑑別すべき疾患は，宿便性潰瘍， サイトメガロウイルス腸炎, NSAIDs 坐剤起因性直腸 病変などがある，宿便性潰瘍は，粪便による粘膜の圧 迫壊死が原因である。単発の深く大きい円形潰瘍を呈 し, 下部直腸や直腸 S 状結腸部に単発, もしくは多 発する. サイトメガロウイルス腸炎は, 深い打ち抜き 様の円形潰瘍を示す. しかし, 浅い潰瘍や輪状潰瘍を 

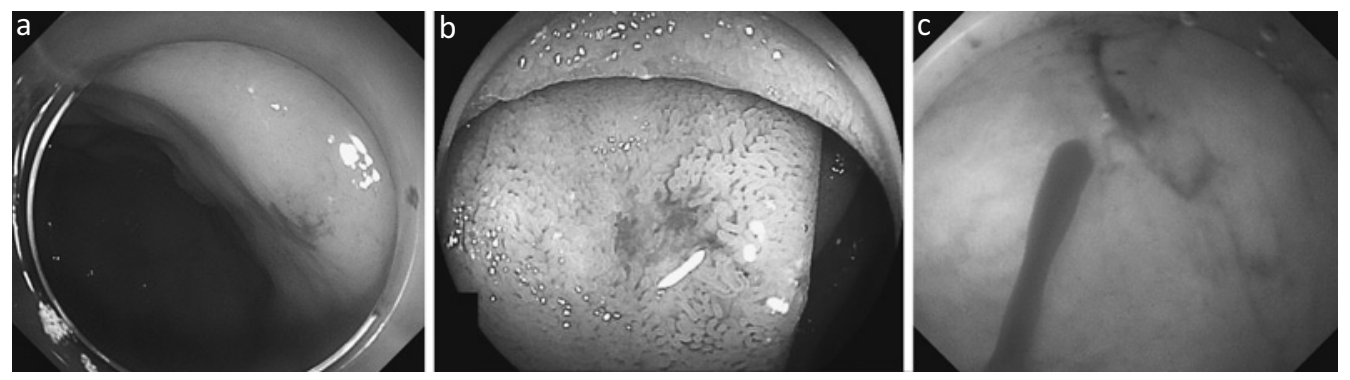

図 5 後天性フォンウイルブランド症候群に伴う消化管 angiodysplasia

$\mathrm{a}$ ：胃, b : 小腸, $\mathrm{c}$ : 大腸

示すことも比較的多い，直腸は好発部位であるが，歯 状線直上にのみ病変を来すことは少なく, 他部位にも 病変がみられることが多い。サイトメガロウイルス腸 炎を疑う場合は，関連する検査を行う必要がある。 NSAIDs 坐剂起因性直腸病変は, 病変は多発性かつ全 周性で，下部直腸から上部直腸に及ぶ比較的広範囲に 分布し, 潰瘍性病変では, 輪状潰瘍, 不整形潰瘍, Dieulafoy 潰瘍などを呈する。これら 3 疾患では，歯状線 直上の下部直腸に限局する輪状潰瘍や帯状潰瘍はみら れないことが, 急性出血性直腸潰瘍との鑑別点である.

\section{高齢者の angiodysplasia や原因不明 の消化管出血では併存疾患の存在に注 意が必要である}

高齢者においては，貧血を認め消化管出血を疑った 場合，比較的負担の少ない上部消化管内視鏡検査を行 い出血の原因となるような所見を指摘できなければ, 原因不明の消化管出血として積極的に精査が行われず に経過観察されている症例が多い。このような症例で は，貧血の症状によりフレイルが増悪するなど問題が ある。近年，これら原因不明の消化管出血とされてい る症例において, 後天性フォンウイルブランド症候群 に伴う消化管出血が一因であることが明らかとなっ た ${ }^{9)}$. 高いずり応力が生じる心・血管疾患である大動 脈弁狭窄症，閉塞性肥大型心筋症，肺動脈性肺高血圧 症，慢性肺血栓性肺高血圧症，僧帽弁閉鎖不全症など においては, 高ずり応力によってフォンウイルブラン ド因子高分子多量体の分解が艺進し, 止血機能に重要
なフォンウィルブランド因子の機能異常が生じ,さら に消化管粘膜に angiodysplasia が形成され消化管出血 の合併出血性疾患である後天性フォンウィルブランド 症候群を発症する（図 4) ${ }^{10)}$ 。全消化管に angiodysplasia（図 5）が形成されるが，その病態に関しては未だ 不明な点が多い。診断においては，一般的な凝固に関 する項目は正常範囲内であることが多く診断には有用 であることは少ない.フォンウィルブランド因子高分 子多量体の定量化に関しては診断に有用であるが，現 在，保険診療では行うことができない，消化管内視鏡 検査は診断に有用であるが，高齢者や超高齢者が多く 心機能が低下しているため, 積極的に検査を行うこと はリスクを伴う。以上から，循環器疾患を併存する高 齢者の原因不明の消化管出血においては, 後天性フォ ンウィルブランド症候群に伴う angiodysplasia からの 出血なども念頭において慎重に診療を進めるべきであ る.

著者の COI（Conflict of Interest）開示：本論文発表内 容に関連して特に申告なし

\section{文献}

1) Oakland K, Guy R, Uberoi R, Hogg R, Mortensen N, Murphy MF, et al: Acute lower GI bleeding in the UK: patient characteristics, interventions and outcomes in the first nationwide audit. Gut 2018; 67 (4): 654-662.

2) Kinjo K, Matsui $T$, Hisabe $T$, Ishihara $H$, Maki $S$, Chuman K, et al.: Increase in colonic diverticular hem- 
orrhage and confounding factors. World J Gastrointest Pharmacol Ther 2016; 7 (3): 440-446.

3) Yuhara H, Corley DA, Nakahara F, Nakajima T, Koike J, Igarashi M, et al.: Aspirin and non-aspirin NSAIDs increase risk of colonic diverticular bleeding: a systematic review and meta-analysis. J Gastroenterol 2014; 49 (6): 992-1000.

4) Niikura R, Yasunaga $H$, Yamaji $Y$, Horiguchi $H$, Fushimi K, Yamada A, et al: Factors affecting inhospital mortality in patients with lower gastrointestinal tract bleeding: a retrospective study using a national database in Japan. J Gastroenterol 2015; 50 (5): 533-540.

5) Jensen DM, Ohning GV, Kovacs TO, Jutabha R, Ghassemi K, Dulai GS, et al.: Natural history of definitive diverticular hemorrhage based on stigmata of recent hemorrhage and colonoscopic Doppler blood flow monitoring for risk stratification and definitive hemo- stasis. Gastrointest Endosc 2016; 83 (2): 416-423.

6) Niikura R, Nagata N, Yamada A, Akiyama J, Shimbo $\mathrm{T}$, Uemura N: Recurrence of colonic diverticular bleeding and associated risk factors. Colorectal Dis 2012; 14 (3): 302-305.

7）中村 志, 飯室 正, 樋田 信, 應田 義, 福永 健, 横山 陽ほか：高齢者非腫瘍性疾患の特徵 急性出血 性直腸潰瘍．胃と腸 $2012 ; 47$ (12): 1850-1858.

8）大川 清, 青木 哲, 上田 渉, 大庭 宏, 宮野 正, 小野 洋ほか：非腫瘍性疾患 急性出血性直腸潰瘍.

胃と腸 2018; 53 (7): 1028-1030.

9) Loscalzo J: From clinical observation to mechanism-Heyde’s syndrome. N Engl J Med 2012; 367 (20): 19541956.

10) Horiuchi $\mathrm{H}$, Matsumoto M, Kokame K: Clinical impact of acquired von Willebrand syndrome associated with cardiovascular diseases. 血栓止血誌 2016; 27 (3): 316321. 